\title{
外来手術として行なら鼓膜形成術
}

\author{
磯野 道夫・福山 泰彦・村田 清高*
}

\section{Tympanic Membrane Perforations Closed with Fibrin Glue}

\author{
Michio Isono and Yasuhiko Fukuyama \\ (Shiroyama Hospital) \\ Kiyotaka Murata \\ (Kinki University School of Medicine)
}

\begin{abstract}
We attempted to close 26 eardrum perforations with fibrin glue in Shiroyama Hospital from November, 1990 to October, 1992 with a success rate of approximately 96\%. The average hearing improvement was $17.7 \mathrm{~dB}$. This procedure can be carried out in one day but the patients must be carefully selected. Dry central perforation is the best indication for this procedure, but if careful inspection of the middle ear through the perforation is carried out, patients with slight ear discharge can be helped by this procedure.

We used autograft temporal fascia in almost all cases. After denuding of the perforation margin, several small pieces of gelatin sponge were placed in the middle ear just beneath the perforation to support the fascia in place beneath the perforation. The fascia was then pulled into the middle ear through the perforation and made to fit on the drum beneath the perforation. A small amount of fibrin glue was dripped onto the lateral margin of the perforation.

This technique can be used not only for small perforations, but also for large perforations which lack a posterior margin or total perforations of the membrane. This technique is very useful in the preservation of the tympano-meatal angle of the membrane and prevents lateralization of the membrane in the future. In addition, this technique with some modifications can be extended to tympanoplasty.
\end{abstract}

Key words: myringoplasty, fibrin glue, tympano-meatal angle, lateralization of tympanic membrane

はじめに

我々は数年前から主にフィブリン糊を用いた 経外耳道鼓膜形成術を外来手術として施行して おり，その症例数は約30例に達した。このフィ ブリン糊を用いた鼓膜形成術は侵襲が小さいた
め，入院する必要がなく，様々な理由により鼓 膜穿孔を閉じる機会を得られなかった患者にと って手軽に鼓膜形成を受けられるといら大きな 利点がある1) 3)。 これらの症例を中心にその有 用性，適応等について述べ，さらに本法を鼓室 
形成術に応用する試みについて言及する。

\section{対象症例}

検討の対象としたのは，春秋会城山病院にお いて，平成 2 年 11 月より平成 4 年10月までの 2 年間に経外耳道的に主にフィブリン糊を用いて 鼓膜形成術を行なった26例である．対象年齢は， 10歳代から80歳代に及んだ．全体的に女性が多 く, 最も多かったのは40歳代で, 次いで60歳代 であった（図 1 )。原則として，外来患者を対象 とし，手術後帰宅させた。例外として反対側耳 の鼓室形成術のため入院中であった例 ( 2 例)や 患者の希望で手術日のみ入院した例（1 例）もあ った．通常の鼓室形成術（入院して行なら中耳 清掃と鼓室形成術を通常の鼓室形成術とする) を行なわずに本法を選択した理由を表 1 にまと めた．水泳を希望する症例（6例)や，社会的理 由(仕事多忙 6 例)やどらしても入院を拒否する 症例 ( 7 例)が多かった。 その他，反対側耳は通 常の鼓室形成術のため入院中で，入院期間中に

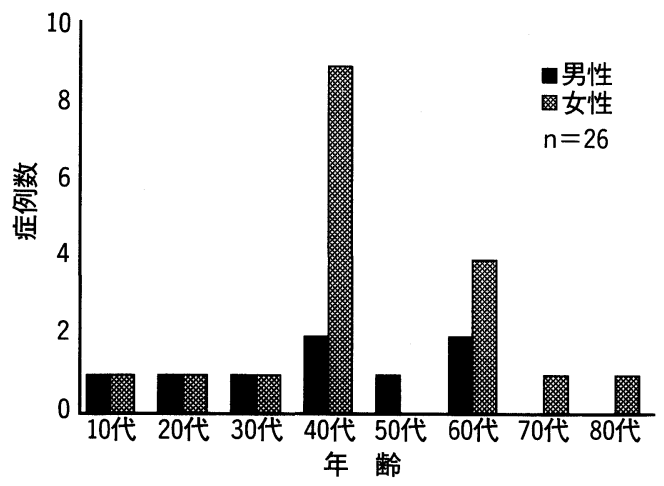

図 1 年齢・性差

表 1 本法選択の理由

\begin{tabular}{lc}
\hline \hline \multicolumn{1}{c}{ 本法の選択理由 } & 症例数 \\
\hline 入院拒否 & 7 \\
仕事多忙 & 6 \\
水泳希望 & 6 \\
反対側鼓室形成術で入院中 & 3 \\
高齢 & 2 \\
全身的要因 & 2 \\
反対側高度感音難聴 & 1
\end{tabular}

軽症の穿孔耳の治療を希望していた 3 例があっ た．全身的要因や高齢のため通常の鼓室形成術 の施行がためらわれた例が 2 例ずつあった．反 対側高度感音難聴で通常の鼓室形成術の施行が ためらわれた 1 例もあった（表 1 で選択理由に 1 例の重複あり)。

\section{術前所見}

適応としたのは，原則として少なくとも 6 カ 月以上明らかな耳漏のなかった単純穿孔性中耳 炎（18例）であるが，軽度の漿液性耳漏を過去 6 カ月以内あるいは手術時に拈いて認めた例 ( 8 例）もあった（表 2 ）。しかし明らかな化膿性耳 漏を認めた症例や真珠腫が疑われた症例は本法 の適応外とした。術前診断の内訳は，単純性穿 孔性中耳炎18例，陳旧性外傷性鼓膜穿孔(明ら かに鼓膜外傷の既往のあるもの）6 例，鼓膜穿

表 2 術前の鼓室粘膜の状態

\begin{tabular}{cccc}
\hline \hline 鼓室粘膜の状態 & \multicolumn{2}{c}{ 症例数 } \\
\hline 乾 燥 & 18 & $(69 \%)$ \\
湿 潤 & 8 & $(31 \%)$ \\
\hline & 合 計 & 26 & $(100 \%)$
\end{tabular}

表 3 術前診断

\begin{tabular}{crr}
\hline \hline \multicolumn{1}{c}{ 術前診断 } & \multicolumn{2}{c}{ 症例数 } \\
\hline 単純性穿孔性中耳炎 & 18 & $(69 \%)$ \\
陳旧性外傷性鼓膜穿孔 & 6 & $(23 \%)$ \\
穿孔性中耳炎(鼓膜の癒着) & 1 & $(4 \%)$ \\
鼓室硬化症 & 1 & $(4 \%)$ \\
\hline 合 計 & $26 \quad(100 \%)$
\end{tabular}

表 4 術前の鼓膜穿孔の大きさ

\begin{tabular}{ccc}
\hline \hline 穿孔の大きさ & \multicolumn{2}{c}{ 症例数 } \\
\hline 全欠損 & 2 & $(8 \%)$ \\
大穿孔 & 5 & $(19 \%)$ \\
中穿孔 & 5 & $(19 \%)$ \\
小穿孔 & 14 & $(54 \%)$ \\
\hline 合 計 & 26 & $(100 \%)$
\end{tabular}


孔があり鼓膜の一部が癒着していた例および鼓 室硬化症各 1 例であった(表 3 )。これらの穿孔 の大きさを分類すると全欠損(完全に緊張部を 欠如している) 2 例, 大穿孔(緊張部の大部分を 欠如している) 5 例，中穿孔(緊張部の中心性穿 孔） 5 例，そして小穿孔 ( $3 \mathrm{~mm}$ 以下の穿孔) 14 例であった(表 4 ).

\section{手術方法}

(1)麻酔は $1 \% \mathrm{E}$ キシロカインを使用し，耳介 上部と外耳道に浸潤麻酔を行なう。(2)耳介上部 に約 $2 \sim 3 \mathrm{~cm}$ 程度の切開を行ない, 側頭筋膜 を採取する，必要な大ささを採取した後，その まま創を閉じる。(3)角膜剪刀にて鼓膜穿孔縁の 新鮮化を行なう。次に穿孔部より鼓室内へジェ ルフォームを挿入し, 鼓室腔を満たす. (4)採取 した筋膜を少し鼓膜面から盛り上がるようにジ ェルフォームと穿孔部との間に挿入する。 (5)こ の上からフィブリン糊(ドイッ，ベーリング社 製ベリプラスト $\left.\mathrm{P}^{\circledR}\right)$ を滴下し筋膜を固定する （図 $2 \sim 4$ ). (6)鼓膜穿孔が大きい場合や鼓膜輪 が欠如している場合，外耳道後壁に鼓膜に対し て平行に切開を加光，外耳道後壁皮膚をトンネ ル状とし，そこより筋膜を挿入し固定を容易に した。この場合も穿孔縁の処置は同様に行なっ た（図 5，6）。(7)今回の症例に施行した術式を まとめると，穿孔縁の新鮮化のみを行なったも
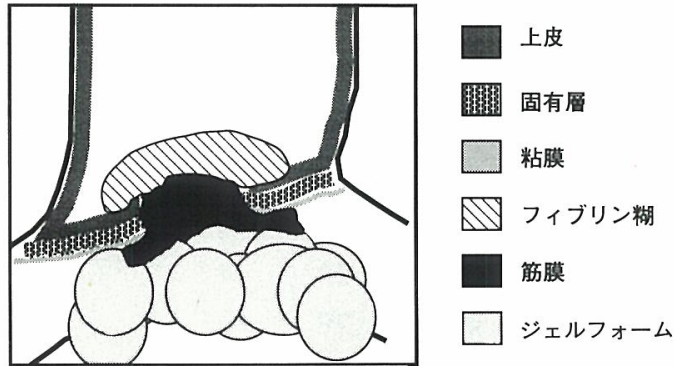

図 2 フィブリン糊を用いた鼓膜形成術の基本的 操作

鼓膜穿孔縁の鼓室腔側へジェルフォームを充填 し，鼓膜とジェルフォームの間へ筋膜を挟み込を. そして，その上よりフィブリン糊を滴下すること により筋膜を固定する.
のは22例で，これに上記したような外耳道後壁 の切除を加光たものが 3 例， また鼓膜が promontorium に癒着していたため筋膜挿入以前 に，癒着剝離をまず行なわなければならなかっ

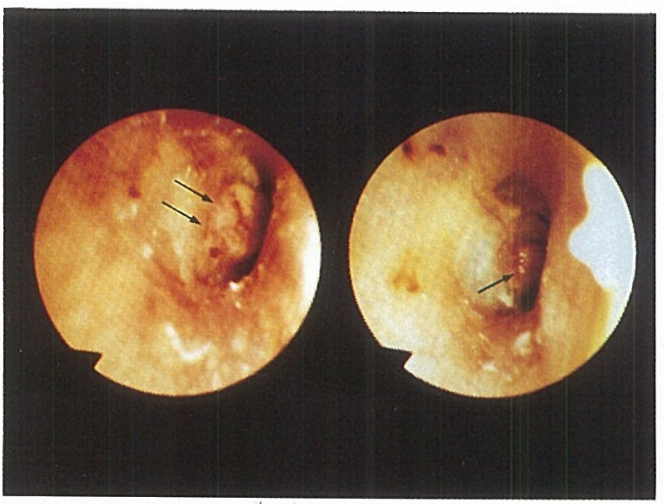

図 3 写真左 (矢印) は術後 2 週目の鼓膜所見. 筋膜はまだ腫脹している。

写真右(矢印) は術後 1 力月目の所見. 筋膜の腫脹は軽減している.

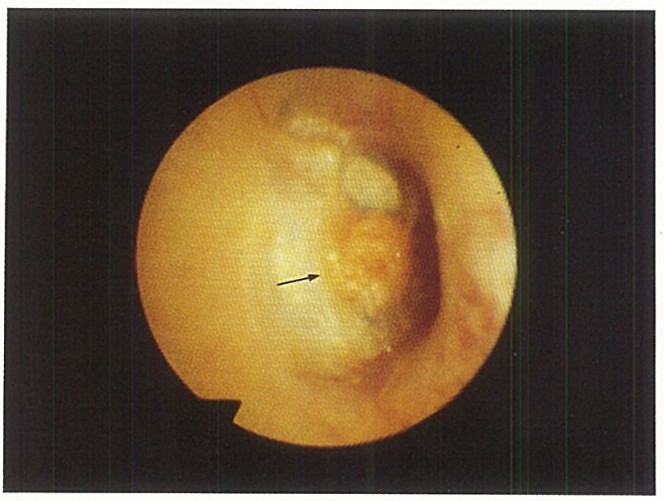

図4同症例の術後 6 力月目の所見 筋膜(知印)は完全に生着している。

表 5 本検討にて行なった術式のまとめ

\begin{tabular}{crc}
\hline \hline 術 式 & 症例数 \\
\hline 穿孔縁の新鮮化のみ & 22 & $(84.6 \%)$ \\
外耳道後壁の切除 & 3 & $(11.5 \%)$ \\
瘉着剥離 & 1 & $(3.9 \%)$ \\
\hline 合 計 & 26 & $(100 \%)$
\end{tabular}




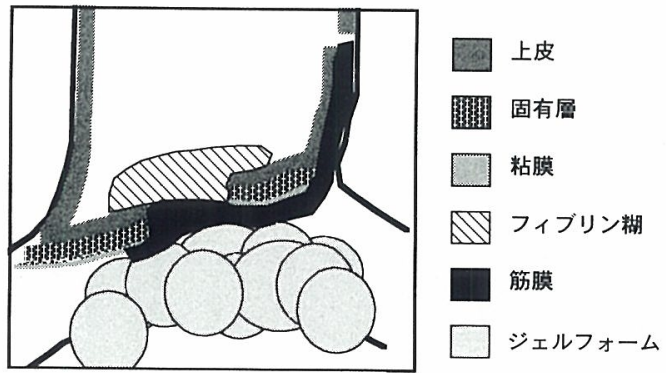

図 5 鼓膜穿孔が大きい場合や鼓膜輪が欠如して いる場合，外耳道後壁に切開を加宇，そこ へ筋膜を挿入することにより固定する.

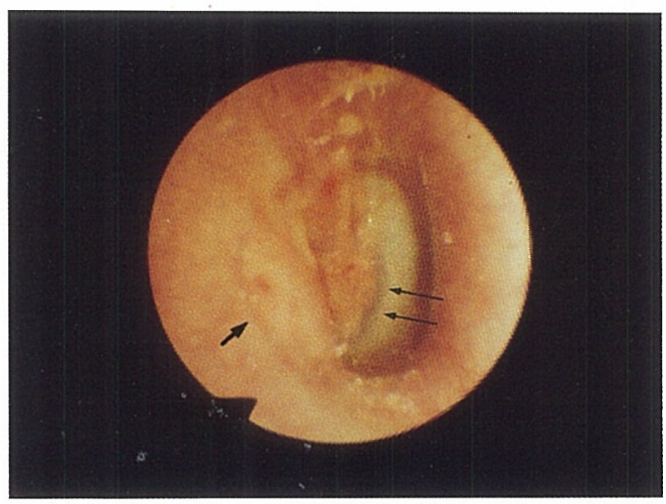

図 6 鼓膜後方の鼓膜輪が欠如している場合，外 耳道後壁に切開を加穴 (矢印左)，そこへ筋 膜(矢印右)を挿入することにより固定し穿 孔を閉鎖する。
た例が 1 例あった(表 5 )。

\section{聴力所見}

聴力に関しては術後 6 カ月以上経過を観察で きた18例について検討した．気導聴力では，悪 化もしくは不変の 2 例 $(11 \%)$ を除き16例に聴力 の改善が得られた。術後 6 力月目に抢けるこれ ら18例の平均聴力の改善は $17.7 \mathrm{~dB}$ であった。 これらの症例の改善度の内訳を見てみると，1 $\sim 10 \mathrm{~dB}$ までの改善が $28 \%$ と最も多く，次いで 11〜20 dB 改善および 21〜30 dB 改善が22\%, $31 \sim 40 \mathrm{~dB}$ 改善が11\%，41〜50 dB 改善が $6 \%$ であった(図 7 )。

\section{術後鼓膜所見}

術後，鼓膜穿孔の閉鎖状態を検討した，検討 方法としては術後 1 週目にタンポンを抜去し, 術後 4 週目に成否を判断した. その時点で完全 に穿孔が閉鎖していたものを完全閉鎖とした。 完全閉鎖は22例(84.6\%)であった。また筋膜は 大部分生着したが，辺縁に小穿孔が残存するも その後閉鎖した例が 3 例(11.5\%) あった。穿 孔が残った例が 1 例(3.9\%)あった（表 6 ).

\section{考察}

1. 鼓膜穿孔閉鎖法の概説

鼓膜穿孔を保存的に閉じる試みは古くからい ろいると行なわれている，過去の報告ををとめ

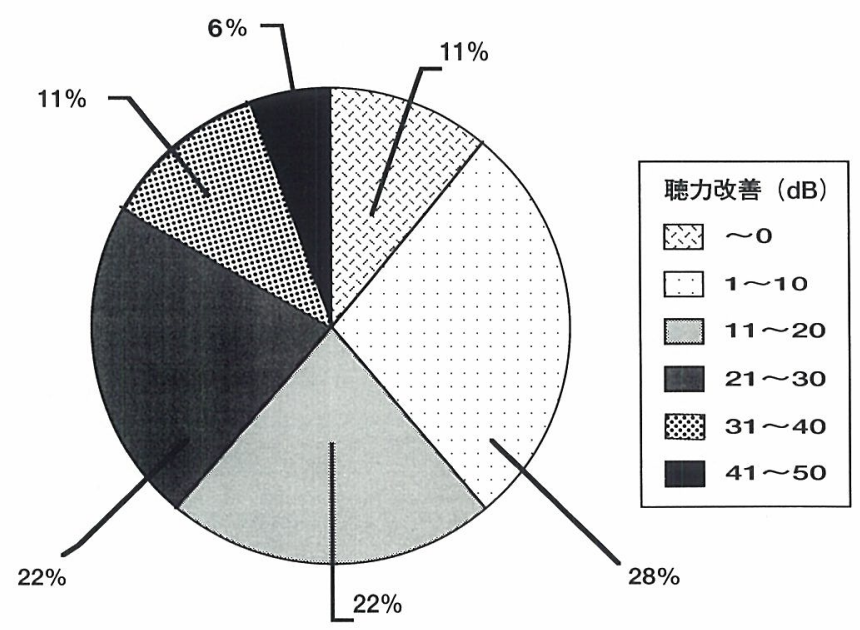

図 7 本法による気導聴力の改善 
ると大きく 2 つに分類できる。一つはまさに保 存的方法と言えるもので，穿孔縁を刺激したり， あるいは穿孔部にパッチをあてて穿孔の閉鎖を 促進させる方法である．穿孔縁を新鮮化するた め鼓膜切開刀や注射針で刺激する方法やトリク ロール酢酸を穿孔縁に塗布することにより閉鎖 を促す方法4をはじめとして様々なものがある. パッチをあてる方法ではコラーゲン膜によるパ ッチ法5), ペーパーテープパッチによる方法6), キチン膜による方法7)8)などがある。残念なが ら，これらの方法ではまず鼓膜穿孔は小さいこ とが第一条件で，治癒せしめ得る鼓膜穿孔の大 きさに限界があったことは否めない。しかし， パッチをあてる方法では極めて容易に聴力改善 を得られることがあるので外来診療に抢ける第 一段階の治療としての利用価值は失われてはい ない。もら一つは䈌密な意味では保存的とは言 えないが，侵襲が少なく外来手術としても行な らことができる方法で，これらは主に自家移植 片を何らかの方法で穿孔部に密着させることを 意図したものである，静脈壁を使用する方法9), 耳垂部脂肪を用いる方法 ${ }^{10)}$, 結合織を充填する 方法 ${ }^{11)}$ ，結合織をフィブリン糊で接着する方 法1) 3)，同種組織を用いる方法12)などがある. これらの方法では同種組織を用いる方法12) 以 外はどこかから移植片を採取しなければならな いといら不利な点があるが，注とんどの方法で パッチ法に較べて大きな穿孔を閉鎖できる利点 がある。ちなみに，最近の報告ではフィブリン 糊を使用することが多いようであるが，本邦で 鼓膜形成術にフィブリン糊を使用したとの記載

表 6 術後の鼓膜所見

\begin{tabular}{crc}
\hline \hline \multicolumn{1}{c}{ 術後鼓膜所見 } & 症例数 \\
\hline 完全閉鎖 & 22 & $(84.6 \%)$ \\
小穿孔残存するも閉鎖 & 3 & $(11.5 \%)$ \\
小穿孔残存 & 1 & $(3.9 \%)$ \\
\hline 合 計 & 26 & $(100 \%)$
\end{tabular}

完全閉鎖は術後 4 週目に穿孔が完全に閉鎖してい ると判断できた例.
があるのは，村上ら ${ }^{13)}$ の報告が初めてのよう である、いずれにせよ，これらの方法では適応 を誤らなければ大きな鼓膜穿孔であっても閉鎖 することができ，穿孔部以外の残存鼓膜に汪と んど触れずに手術が行なえるため，移植片が生 着しさえすれば極めて生理的状態に近い状態に なるといら大きな利点があると考えられる.

2 . 湯浅らの方法

湯浅ら 1) 3) の報告をまとめると次のようにな る。

1 ) 適応は耳漏, 真珠腫の無い緊張部穿孔で, 穿孔の大きさは針穴大から全欠損まですべて適 応となる。

2 ) 切開部位は耳介後部とする. 移植材料は 厚めの皮下組織が最もよい。

3 ）鼓膜に対する麻酔は基本的には鼓膜麻酔 液で行ない, 辺縁性穿孔, 大穿孔の場合には浸 潤麻酔を行なう。

4 ）残存鼓膜の処理では鋭ピックを用いて穿 孔縁全周を $1 \mathrm{~mm}$ 前後切除する.

5 ）移植片は穿孔に見合った大ささにトリミ ングレた後, アンダーレイ法を行なら。中耳腔 には何も入れない，接触不全のないことを確認 した後，フィブリン液を $23 \sim 25 \mathrm{G}$ のカテラン 針を用いA 液から 1 滴ずつ, 接触部位 $3 \sim 4$ 力 所に滴下寸る. 辺縁性穿孔の場合には移植片の 一部を外耳道後部で皮虐と骨面に挟久こむ．外 耳道には何もタンポン充填しない。

6 ）タンポン充填しないので術直後から移植 片の観察が可能である.

7 ) 術後再穿孔症例に関しては, 早期のもの は移植片を引き出し再接着するだけでよいが， 2 週間以上経過したものでは穿孔縁の再新鮮化 が必要である. 直径 $1 \mathrm{~mm}$ 以下の小穿孔はその まま 6 力月は観察して，拡大傾向のあるものは 1 年経過してから再閉鎖を試みる.

また，湯浅ら 1) 3) はこの方法の利点をいくつ かあげている、これらをまとめると，患者にと っての利点としては, (1)入院を必要としない。 (2)麻酔による侵襲が少ないので術後飲食, 就業, 
就学が可能である. (3)適応年歯が広い. (4)術直 後より聴力改善が得られる. (5)聴力改善の期待 がなくとも術後水泳可能になり二次感染を回避 し得る. (6)手術侵襲が少ないので反対側が高度 感音難聴，䆍でも適応になる。また，術式とし て優れている点は, (1)手術操作の難易度が低く, チューブ挿入術に近い，(2)術直後より聴力はパ ッチ聴力に近く改善され，経過とともにそれを 越えることも稀ではない。(3)残存鼓膜が注とん ど温存されるため，新生鼓膜は極めて自然な形 に形成される．以上が，湯浅らの方法1) 3) (以 下湯浅法と略す)の概略である。これを見ると 極めて非侵襲的で完成度の高い優れた方法であ ると思われる。

\section{3 . 我々の方法}

湯浅法はいくつかの点で我々の方法と異なる. 我々の方法と比較検討することにより，その相 違点をまとめてみたい。

\section{1 ）適応に関して}

湯浅法は我々の考光と大略差はないと思われ る. しかし，手術の 1 力月以上前の手術決定時 には全く耳漏がなかったが，手術の 2 週間前に 感染を起こし耳漏を認めた例もあった。この例 では抗生剂で治療し，耳漏を止め，予定どおり 手術を施行し，術後耳漏を来すこともなく筋膜 は生着した。したがって，耳漏の有無は手術適 応の判定に必ずしも $100 \%$ 重要な所見ではない と思われる．外部からの感染の可能性がある場 合，多少の漿液性耳漏があってもむしろ鼓膜を 閉鎖することによって感染を防止できることも ありうる．鼓室粘膜が薄く血管が透視できる程 度であったり軽い浮腫が見られる程度であれば 問題はない。

聴力に関しての適応では湯浅法と大差はない。 しかし，適応の決定は実はかなり難しい側面を もっている．例觉ば小さな穿孔の場合，湯浅法 あるいは我々の方法を用いれば簡単に短時間で 確実に閉鎖できるのであるが，少し時間はかか ってもパッチ法で閉じることができる症例もあ る、実際，入院しないで済むこの方法でさえ手
術と聞くだけでためらら患者も存在するわけで, より非侵襲的なパッチ法でうまくいく可能性が あるならば，まずはその方法を試みるのもよい と考光られる. 我々は穿孔の大ささや状態にも よるが，キチン膜による閉鎖法718) を先行させ る場合もある。

2 ) 移植材料に関して

切開部位の違いも関係するが，我々は側頭筋 膜が最善と考光ている. 我々の例では側頭筋膜 が皮下結合組織に較べ密着性が劣るよらなこと はなかった．筋膜の採取部位に関しては我々は 耳介上部の頭髪を約 $2 \mathrm{~cm}$ 剃毛した後, 約 1.5 $\mathrm{cm}$ 切開し側頭筋膜を採取している。これは, この程度の剃毛範囲であれば美容上の問題はな いし，頭髪の中であれば術後に創が見えなくな るためこちらの方がよいといら患者が多かった ためである。ささらに，この部が側頭筋膜を無理 なく採取できるためである14)。したがって，我 我は手術手技上の手間は汪とんど同じであるた め穿孔の大ささにかかわらず，大部分の症例で 移植片として筋膜を採用している.

3 ）麻酔について

我々の方法と湯浅法とは大きく異なる，我々 は全例で通常の局麻の鼓室形成術と同様に $1 \%$

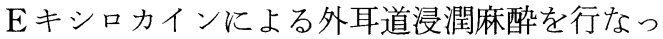
ている．この方が麻酔効果が確実であるし，鼓 膜穿孔縁の状態によって切除範囲を予想よりも 大きく広げなければならない例掞よび辺縁性穿 孔あるいは大穿孔例にも常に対応できるからで ある。

4) 穿孔縁の処理について

我々は角膜剪刀を用いることが最も多かった。

5 ) 移植片について

湯浅法では中耳腔には何も入れないが，我々 はなるべく鼓室内にジェルフォームを充填する よらにしている、なぜならば，穿孔が小さい場 合はジェルフォームを充填しなくても問題はな いが，大きい場合には充填した方が筋膜を固定 しやすいからである。ささらに、ジェルフォーム を充填することにより，穿孔の大きさにもよる 
が，フィブリン糊を使用しなくてもよい場合も でてくる. 実際, 小穿孔の 3 例ではフィブリン 糊を使用せず，ジェルフォームとキチン膜のみ の使用で筋膜を生着できた。また，湯浅法では フィブリン液の滴下法に関してかなり細かい点 に注意を払っているが，我々は，筋膜の外耳道 側からの固定を意図しているだけなので, 単に 鼓膜の上に寒天状の膜を作るにすぎない，湯浅 法はフィブリン糊の接着力にこだわった方法で あるのに対し, 我々の方法は筋膜の固定の一手 段としてフィブリン糊を使用しているにすぎな いといえる。中耳腔側はジェルフォームと鼓膜 の粘膜層の間に挟み込むことにより固定し，外 耳道側からフィブリン糊で筋膜と鼓膜を接着す ることにより鼓室腔へ脱落することを防止して いる. このことは, 後述する通常の鼓室形成術 に拉けるアンダーレイ法への応用で役に立つこ とになる，辺縁性穿孔の場合には，外耳道後壁 に切開を加え上皮を剝離し，外耳道上皮をトン ネル状とし，その中に筋膜を通すことにより筋 膜を固定する方法をとる。なぜならば，筋膜を 鼓膜穿孔縁のどこかに接着させね柿ならないが， 穿孔が大きい場合や鼓膜輪を欠如しているとき はそのような部位が鼓膜側にないため，どこか 飞筋膜を固定する場所を確保する必要があるか らである。この方法は技術的には難しいが，筋 膜の固定がよいため筋膜の生着はむしろよいと 考兄られる.

6 ) 術後処置について

湯浅法に対し, 我々は術後固定のためタンポ ン充填を行なう，移植片の固定とドレナージの 意味で通常の鼓室形成術と同様に約 1 週間は夕 ンポンを留置する.

7 ）術後再穿孔症例に対する処置に関して

我々は術後 1 力月は放置するが， 1 力月を過 ぎれば穿孔縁の新鮮化とキチン膜をあて上皮化 を促すことにより閉鎖している。この方法で小 穿孔であれば $1 \sim 2$ 力月で再穿孔は閉鎖し得る.

本法の難易度については，拈そらくかなりの 鼓室形成術の経験が必要であろうし，単純に簡
易であるというには問題があると思う。まして や大穿孔例に関しては, 耳介後部切開によるサ ンドウィッチ法の方が術者にとってはよほど簡 易であると思う。湯浅法あるいは我々の方法の 最大の利点はむしろ残存鼓膜に汪とんぞ触れる ことなく手術を行なえるといら点にある。つま り，労せずに tympano-meatal angle を完全に 温存できることである. 鼓膜前方の形態を温存 できる利点は非常に大きい. 我々は将来的な鼓 膜の外側化の予防の意味で, サンドウィッチ法 に执いても tympano-meatal angle の温存に常 に最大の注意を払っている. 湯浅法あるいは我 我の方法は全くここには触れずに手術を行なら ので，鼓膜の外側化を起こさない手術が結果的 に行なえていることになる. 我々はこれを通常 行なっている鼓室形成術(耳介後部切開を行な ら)へ応用している。例えば，普通はサンドウ ィッチ法を行なら例でも穿孔が鼓膜前方にある 場合，穿孔前縁の鼓膜は上皮の剝離を行なわず に穿孔縁の新鮮化のみにとどめ，筫膜をアン ダーレイとしフィブリン糊で固定する.こうす ることにより，鼓膜前方は剥離を行なわずに tympano-meatal angleを温存することが可能 となる。これは, 初めはサンドウィッチ法を意 図しても上皮の剝離が困難であったり，らっか り上皮を破ってしまい穿孔縁に上皮が残存して いるかどうか自信が持てない場合，この方法で アンダーレイにすると安心である。フィブリン 糊による固定により従来のアンダーレイ法の弱 点を補ったことにもなる.尚, この場合でも鼓 膜後方の筋膜は固有層と上皮の間に挟むので筋 膜の生着は極めてよい(図 8，9).

\section{4. 我々の成績}

1 ）年齢・性差

中年の女性に最も多く見られた（9例）のは， 本手術の適応となるような中耳炎は比較的軽症 なため，わざわざ仕事を休んで外来を受診する 男性が少なかったためであろう，今回，本法の 適応となった症例には漫然と長い期間通院治療 していたり，手術を勧められても入院を拒否し 
耳漏が出ない限り耳鼻科を受診しないよらなタ イプの患者が多いよらに思われる. 全員聴力改 善を希望はしたが，それ核ど強い希望ではない 場合が多かった。 むしろ, 強い希望として多か ったのは水泳希望（6例）であった。これは，明 らかに入院する必要がないといら利点がもたら した結果である。

2 ) 術前診断

明らかな外傷の記憶のない単純性穿孔性中耳 炎と明らかな外傷の既往のある陳旧性鼓膜穿孔 例に大別できる。一方, 術前の鼓膜穿孔の大き さをみると小穿孔が最も多かった，これは，化 膿性耳漏がないような比較的軽度の中耳炎が主

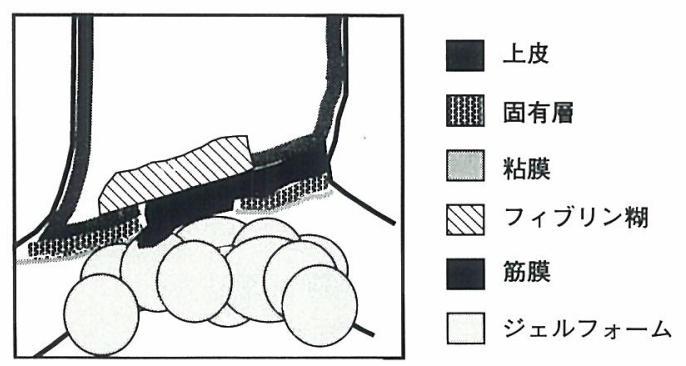

図 8 本法の応用例

耳介後部切開に上る鼓膜形成術の場合, 前方は筋 膜をアンダーレイでフィブリン糊を用い固定し， 後方は上皮と固有層の間に挟む。

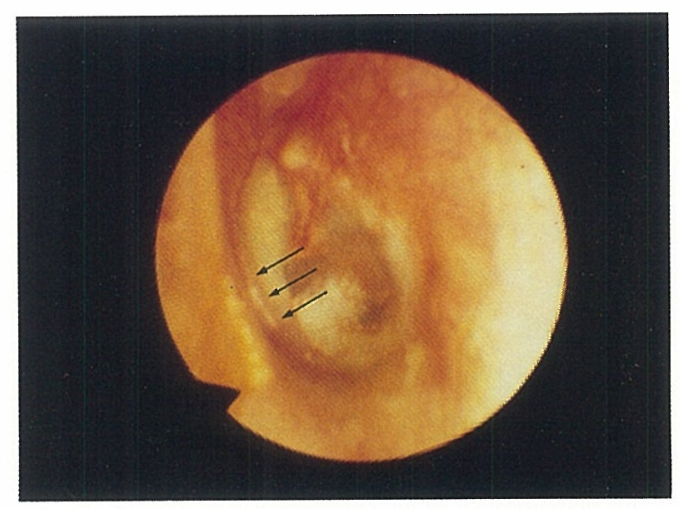

図 9 本法の応用例の術後 6 力月目の鼓膜所見 tympano-meatal angle(矢印)は温存され, 鼓膜の 形態は極めて生理的状態に保たれている.
な適応となるわけであるから当然のことと思わ れる。乙かし, 全欠損めるいは大穿孔の症例 あったことは注目に值するる。これらは本当は耳 介後部切開を行ない通常の鼓室形成術を行なら た方が術者にとっては楽なのであるが，患者の 様々な理由により入院を拒否された例である. この方法を用いなければ手術を受ける機会を得 られなかったであるらと思われるこれらの患者 にとって本法は有用でめったと言光る。

\section{3 ) 聴 力}

本法では必ずしも聴力改善を第一の目的とす る必要はないと考㝋ている。しかし結果的には, その術後聴力所見は満足すべきものであった。

本法の適応となる程度の聴力を有する患者では 反体側は正常の場合も多く, 聴力改善の希望は 強くない場合が多い。むろ，時に扣こる耳漏 が最大の訴えであったり，水泳の希望といった ことの方に関心が向いている場合が多い. 聴力 改善は鼓膜穿孔が大きかった群 (全欠損と大穿 孔)で $23.8 \mathrm{~dB}$ ，小さかった群 (中穿孔と小穿孔) では $14.6 \mathrm{~dB}$ であった。この結果は術前の聴 力が異なるので単純には比較できないが，穿孔 が大きくても，本法は十分に有用であると言え る. 特殊な例として, 次のようなものがあった. 鼓膜が promontrium に瘉着していた例では, 角短針と角膜剪刀で剥離した後, ジェルフォー ム充填を行ない筋膜を挿入した。一方，鼓室硬 化症の例では術前に聴力所見と高空間分解能 CTにて診断がついて抏り15)，パッチテストも 陰性であったが，患者の強い水泳希望と入院拒 否があったため本法を強行した。なるべく石灰 化物 (calcium plaque) を除去する方針で, 鼓膜 の石灰化部を除去し耳小骨の可動性回復を試み たため中程度の大きさの穿孔が鼓膜全欠損とな った. しかし，外耳道後壁を切開してトンネル 状とし，その中を筋膜を通すことにより固定し 鼓膜形成を行なった。耳小骨周团の清掃が充分 でないため, 聴力改善は得られなかったが，筋 膜は生着し水泳は可能となり, 患者は満足して いる.これらの症例は本法の適応を広げる一例 
と考え評価できると思われる。

4 ) 術後鼓膜所見

術後 4 週目で穿孔が完全に閉鎖していたもの は22例(84.6\%)であった。また，この時点では， 小穿孔(多くは筋膜と穿孔縁の間に隙間がある 状態)を認めたものが 3 例(11.5\%) あった。こ れらのうち，2 例は外来にて保存的に閉鎖でき た. 閉鎖しなかった 1 例はやむを得ず再手術を 行なった。再手術は第 1 回手術より穿孔がはる かに小さいため，問題なく閉鎖できた。このよ らに，鼓膜穿孔は注ぼ全例で閉鎖することが可 能であった。たとえ，小穿孔が残ったとしても 術前の穿孔の大きさよりははるかに小さいため 汪とんどの場合保存的に閉鎖できると考光る。 一方，現在も穿孔を認めるのは陳旧性外傷の 1 例のみである。この例は術後 2 週目頃は, 完全 閉鎖したように見えたが，その後感染を起こし， 耳漏が止まった術後 4 週目には，穿孔は術前に 較べ半分程度の大きさにはなったが残存してい た．その後も何度か感染を繰り返すため，耳介 後部切開により鼓室形成術を行なら予定である. 本例は，外傷の後感染を起こし耳漏が出現した ため，穿孔が閉鎖せず，通院治療を続けていた。 $\mathrm{X}$ 線所見にても，鼓室所見にも問題はなく，過 去 6 カ月以内の耳漏もなかったため本法を施行 したが，成功しなかった。原因は不明であるが， 本法の適応決定の難しさを示す一例であろう．

\section{まとめ}

1. 春秋会城山病院に打いて, 平成 2 年11月 より平成 4 年 10 月までの 2 年間に 26 例に外来手 術として主にフィブリン糊を用いて鼓膜形成術 を行なった。

2. 平均聴力の改善は $17.7 \mathrm{~dB}$ であった.

3 ．鼓膜穿孔は $96 \%$ の症例で閉鎖できた。

4. 手術適応に関しては全く耳漏のない症例 のみでなく, 多少の漿液性耳漏のある症例でも 施行可能であった。

5. 手術手技としては全例で側頭筋膜を移植 片として使用し，大部分の症例に対してフィブ リン糊を用いたアンダーレイ法を行なった。一
部の症例ではフィブリン糊は使用せずジェルフ オームとキチン膜の固定のみでも穿孔を閉鎖で きた。

6. 大穿孔例に対しては術式を工夫すること により対処できた。

7. 本法の最大の利点は tympano-meatal angleの温存ができることにあると考えられた。

8. 本法のテクニックは耳介後部切開による 通常の鼓室形成術にも応用可能であった。

\section{結語}

我々の術式が外来手術に留まらず, tympanomeatal angle の処置, 鼓膜の外側化の予防法々 して使えることを述べた。我々の方法は筋膜固 定の一手段としての考光に重点を扔いたもので ある。これはアンダーレイ法の考え方と合わせ ることにより，広く鼓室形成術の際の鼓膜再建 術に応用できる方法として紹介できることを強 調したい。

本論文の要旨は第239回および第243回日本耳鼻咽 喉科学会大阪地方連合会に执いて口演した。

\section{参考文献}

1）湯浅 涼, 西条 茂, 富岡幸子, 他：簡易な鼓 膜形成術一フィブリン糊を用いた接着法一。 耳喉頭頸 61 : 1117 1122, 1989.

2）湯浅 涼, 末武光子, 西条 茂, 他: 接着法に よる鼓膜形成術一その適応, 手技, 遠隔成績 一. Otol Jpn 1:38, 1991.

3）湯浅 涼, 末武光子, 入間田美保子, 他 : 鼓膜 形成術(接着法) 飞於许る技術的諸問題. Otol Jpn $2:$ 499, 1992.

4) Oppenheiner RP : Office treatment of traumatic perforations of the eardrum. GP $37: 95$ $\sim 97,1968$.

5）花岡真子，伊野千代徳，山下敏夫, 他：当科鼓 膜外来の現況. 日耳鼻 $88: 585,1985$.

6) Camnitz PS and Bost WS : Traumatic perforations of the tympanic membrane; early closure with paper tape patching. Otolaryngol Head Neck Surg $93: 220 \sim 223,1985$.

7）山本悦生, 大村正樹, 磯野道夫, 他: 中耳手術 でのベスキチン使用経験. 臨耳 $15 ： 68,1988$. 
8）山本悦生, 大村正樹, 磯野道夫, 他: 中耳手術 でのキチン膜(ベスキチンW)の使用経験. 耳喉 頭頸 62 : 337 342, 1990.

9) Shea JJ : Vein graft closure of eardrum perforations. Arch Otolaryngol Head Neck Surg 72 : 445 447, 1960.

10) Ringenberg JG : Closure of tympanic membrane perforations by the use of fat. Laryngoscope 88 : 982 993, 1978.

11）白幡雄一：鼓膜穿孔閉鎖術；結合織充填移植術. 耳展 $29: 81 \sim 84,1986$.

12）新川 敦, 田村嘉之, 木村栄成, 他: 外来で行 なら同種硬膜を用いる鼓膜形成術. Otol Jpn 2 : 500, 1992.
13）村上嘉彦, 小山英明, 斎藤雄一郎, 他 : 中耳手 術に拈ける生物学的接着剂の応用について. 臨 耳 $10: 120 \sim 121,1983$.

14) Wormald PJ and Alun-Jones $\mathrm{T}$ : Anatomy of the temporalis fascia. J Laryngol Otol 105 : 522 524, 1991.

15）磯野道夫, 山本悦生, 大村正樹, 他: 鼓室硬化 症の臨床．神戸病紀 $29: 75 \sim 80,1990$.

原稿受付 : 平成 4 年12月15日 原稿採択 : 平成 5 年 1 月 29 日 急載 別刷請求先 : 磯野道夫 厂583 大阪府羽电野市古市7-10-5 